\title{
PENYULUHAN, PEMERIKSAAN THT DAN PENGOBATAN GRATIS DALAM PELAYANAN KESEHATAN DAN PENELITIAN (PENITI) 2016 DI DESA GEGELANG KARANGASEM BALI
}

\author{
K.A.R.S. Sentana ${ }^{1}$, K.A. Wiryadana ${ }^{2}$, J.R. Pranata ${ }^{3}$, P.D.S. Rahayu ${ }^{4}$, I.G.A.D.P. \\ Anjani $^{5}$, J.M.A.D. Septiantari ${ }^{6}$, A.R. Dewi ${ }^{7}$, K.A.I. Pitaloka ${ }^{8}$, I.P.G.O. Jaya ${ }^{9}$, I.G.H. \\ Ganesha $^{10}$
}

\begin{abstract}
ABSTRAK
Kesejahteraan suatu negara dapat dilihat dari tingkat kesehatan masyarakatnya. Akan tetapi masyarakat Indonesia masih belum secara merata hidup sehat. Kondisi ekonomi, pendidikan dan geografis menjadi faktor penyulit dalam mewujudkan pemerataan kesehatan. Oleh karena itu diperlukan peran serta berbagai pihak untuk menyukseskan perbaikan derajat kesehatan termasuk salah satunya mahasiswa kedokteran. Desa Gegelang yang merupakan salah satu desa yang terletak di antara perbukitan dengan mayoritas penduduk dengan tingkat pendidikan rendah serta akses pelayanan kesehatan yang kurang memadai merupakan sasaran tepat untuk program pendidikan kesehatan dan pengabdian masyarakat. Selain itu perlu dilakukan penelitian serta analisa data mengenai permasalahan dialami masyarakat desa. Melalui program PENITI 2016 ini, dilakukan kegiatan penyuluhan, penelitian kecacingan siswa SD dan intervensi kesehatan berupa pemeriksaan THT dan pelayanan kesehatan gratis. Kegiatan penelitian, penyuluhan, dan pelayanan kesehatan gratis diikuti secara antusias oleh anak SD Gegelang dan warga sekitar. Dari pelaksanaan kegiatan diperoleh data kecacingan pada siswa SD 3 Gegelang sebesar 31,7\%, permasalahan THT dialami 46\% siswa SD 1 Gegelang dengan 13\% mengalai serumen obsturan. Kecacingan dan serumen obsturan merupakan masalah kesehatan yang dapat menganggu pertumbuhan, perkembangan dan proses belajar siswa. Data masalah kesehatan warga yang datang ke posko pelayanan kesehatan didominasi dengan keluhan nyeri sendi, neuropati dan ISPA.
\end{abstract}

Kata Kunci : pelayanan kesehatan, pengobatan gratis, PENITI 2016, mahasiswa kedokteran

\begin{abstract}
\footnotetext{
${ }^{1}$ Program Studi Pendidikan Dokter, Fakultas Kedokteran Universitas Udayana. Email:rendyagus121@gmail.com, No. HP: 087864536907

${ }^{2}$ Program Studi Pendidikan Dokter, Fakultas Kedokteran Universitas Udayana

${ }^{3}$ Program Studi Pendidikan Dokter, Fakultas Kedokteran Universitas Udayana

${ }^{4}$ Program Studi Pendidikan Dokter, Fakultas Kedokteran Universitas Udayana

${ }^{5}$ Program Studi Pendidikan Dokter, Fakultas Kedokteran Universitas Udayana

${ }^{6}$ Program Studi Pendidikan Dokter, Fakultas Kedokteran Universitas Udayana

${ }^{7}$ Program Studi Pendidikan Dokter, Fakultas Kedokteran Universitas Udayana

${ }^{8}$ Program Studi Pendidikan Dokter, Fakultas Kedokteran Universitas Udayana

${ }^{9}$ Program Studi Pendidikan Dokter, Fakultas Kedokteran Universitas Udayana

${ }^{10}$ Program Studi Pendidikan Dokter, Fakultas Kedokteran Universitas Udayana
}

The welfare of a country can be inferred from the quality of public health. Economic, educational and geographical conditions are complicating factors in realizing good public health. Participation of various parties is needed to improve, including medical students. Gegelang one village located among the hills with the majority of the population with low education and inadequate access to health services is right target for health education and community service programs. In addition, it is necessary to conduct research and data analysis on problems experienced by villagers. Through PENITI 2016 program, we conduct health education, research of helminth infection among elementary school (SD) students and health intervention in the form of ENT examination and free medical service. All of the activities are followed enthusiastically by elementary 
school student and local people. From all those, we obtained data of helminth infection among students SD 3 Gegelang which is $31.7 \%$, ENT problems in $46 \%$ of SD 1 Gegelang with $13 \%$ with serumen obstruction. Helminth infection and serumen obstruction is a health problem that can disrupt the growth, development and learning process of students. Data on health problems of residents who come to health service posts are dominated by joint pain, neuropathy and URTI.

Keywords : health care, free medical service, PENITI 2016, medical student

\section{PENDAHULUAN}

Kesejahteraan dari suatu negara dapat dilihat dari tingkat kesehatan masyarakatnya (Thomas \& Frankenberg, 2002). Kesehatan merupakan hak asasi manusia dan merupakan salah satu unsur kesejahteraan yang harus diwujudkan sesuai cita-cita bangsa Indonesia. Akan tetapi, pada kenyataannya masyarakat Indonesia masih belum secara merata hidup dalam lingkungan sehat, berperilaku sehat, serta belum dapat menjangkau pelayanan kesehatan yang bermutu (Satar et al. 2013). Faktor fundamental seperti kemiskinan dan tingkat pendidikan yang rendah berkontribusi pada rendahnya persepsi masyarakat mengenai kesehatan (Singh \& Singh, 2008). Hal tersebut ditambah kondisi geografis Indonesia yang luas dapat menjadi penyebab akses ke fasilitas kesehatan yang bermutu masih belum dapat dirasakan oleh semua lapisan masyarakat sampai saat ini (Chan et al. 2006).

Usaha peningkatan kesehatan masyarakat dan pelayanan kesehatan merupakan permasalahan yang kompleks, sehingga dibutuhkan kolaborasi antar berbagai pihak (Witteman et al. 2013). Dalam upaya tersebut tenaga kesehatan dan instansi di bidang kesehatan merupakan ujung tombak untuk membantu mewujudkannya. Salah satu pihak yang dapat ikut berperan adalah mahasiswa fakultas kedokteran sebagai calon tenaga kesehatan di masa mendatang. Selain dapat membantu meningkatkan derajat kesehatan masyarakat, melalui kegiatan pengabdian masyarakat mahasiswa dapat terjun langsung ke lapangan untuk melatih keterampilan dalam aplikasi ilmu kedokteran. Hal ini juga dapat melatih mahasiswa berempati dan peduli terhadap permasalahan masyarakat ekonomi lemah terutama dari permasalahan kesehatan.

Himpunan Mahasiswa Kedokteran Umum Fakultas Kedokteran Universitas Udayana (HMKU FK Unud) sebagai wadah penyalur aspirasi mahasiswa kedokteran umum FK Unud menyadari pentingnya peran para mahasiswa FK Unud ke dalam peningkatan kesehatan Indonesia. Melalui Bidang Pengabdian Masyarakat (Pengmas), HMKU FK Unud melaksanakan kegiatan Pelayanan Kesehatan dan Penelitian (PENITI) Himpunan Mahasiswa Kedokteran Umum 2016. Kegiatan PENITI 2016 mencakup penerapan dari Tri Dharma Perguruan Tinggi yang terdiri dari pendidikan, penelitian dan pengabdian masyarakat pada bidang kesehatan.

Kegiatan PENITI dilaksanakan di desa Gegelang yang merupakan salah satu desa yang terletak di antara perbukitan dengan mayoritas penduduk dengan tingkat pendidikan rendah serta akses terhadap pelayanan kesehatan yang kurang memadai. Desa Gegelang merupakan salah satu desa di Karangasem yang mendapatkan program eradikasi kecacingan masal. Program ini meliputi pemberian obat kecacingan dosis tunggal kepada siswa secara periodik. Program telah berjalan secara rutin, akan tetapi perlu dilakukan evaluasi. Oleh karena itu, kegiatan ini juga melakukan penelitian tentang prevalensi kecacingan, faktor-faktor resiko serta hubungannya terhadap status gizi. Selain memberikan pendidikan dan pengabdian, kegiatan ini diharapkan juga dapat memberikan gambaran permasalahan kesehatan yang ada di desa Gegelang melalui penelitian dan analisa data hasil kegiatan pelayanan kesehatan.

\section{METODE PELAKSANAAN}

Kerangka pemecahan masalah yang dilakukan dalam kegiatan ini adalah pendidikan/penyuluhan, penelitian dan intervensi kesehatan/medis sebegai berikut:

\section{1 | BULETIN UDAYANA MENGABDI}


K.A.R.S. Sentana, K.A. Wiryadana, J.R. Pranata, P.D.S. Rahayu, I.G.A.D.P. Anjani, J.M.A.D. Septiantari, A.R. Dewi, K.A.I. Pitaloka, I.P.G.O. Jaya, I.G.H. Ganesha

Pendidikan/penyuluhan: Penyuluhan ini ditekankan pada transfer pengetahuan tentang kesehatan terutama yang berkaitan dengan kebersihan sebagai upaya preventif penyakit diantaranya penyuluhan cara cuci tangan yang baik, cara sikat gigi yang baik, senam serta panduan hidup bersih dan sehat (PHBS). Kegiatan penyuluhan dilakukan oleh mahasiswa panitia dan voluntir kepada siswa SD 1 Gegelang pada tanggal 2 September 2016.

Pelayanan Kesehatan Telinga Hidung Tenggorokan (THT): Dilakukan pemeriksaan kesehatan telinga hidung dan tenggorokan pada siswa SD 1 Gegelang oleh para dokter dari bagian THT-KL FK Unud/RSUP Sanglah Denpasar dibantu oleh panitia dan mahasiswa voluntir. Pembersihan telinga dan pengobatan dilaksanakan langsung di tempat kegiatan sesuai dengan indikasi medis oleh dokter. Kegiatan ini dilaksanakan pada tanggal 2 September 2016.

Penelitian Prevalensi dan Faktor Resiko Kecacingan Serta Status Gizi: Penelitian mengambil sampel siswa SD 3 Gegelang dengan metode total sampling. Pemeriksaan feses dan wawancara dilakukan pada siswa SD 3 gegelang untuk mengevaluasi faktor-faktor serta jumlah siswa dengan kecacingan. Feses pagi hari dikumpulkan oleh siswa masing-masing, kemudian dikumpulkan dan dianalisa oleh panitia dan analis kesehatan terlatih dari Laboratorium Parasitologi FK Unud dengan metode direct smear menggunakan eosin $2 \%$. Hasil apusan kemudian diamati di bawah mikroskop untuk mencari gambaran telur cacing. Data mengenai faktor-faktor resiko terkait penyakit kecacingan diperoleh dengan wawancara. Data status gizi diperoleh dengan melakukan pengukuran berat badan, tinggi badan dan indeks massa tubuh yang kemudian dibandingkan dengan nilai acuan berdasarkan usia dari WHO. Data hasil wawancara, pemeriksaan feses dan status gizi dianalisis dengan metode statistik Chi-square dan rasio odd dengan menggunakan perangkat lunak spss v21. Kegiatan ini dilaksanakan pada tanggal 2 September 2016.

Pelayanan Kesehatan: Pengobatan gratis bagi masyarakat dari berbagai golongan dan usia dilakukan dengan membuat posko di Bale Banjar desa Gegelang. Pemeriksaan dan pengobatan dilakukan oleh dokter umum (alumni FK Unud), dokter spesialis anak (bagian Pediatri RSUP Sanglah, Denpasar), dan dokter spesialis penyakit dalam (bagian penyakit dalam RSUP Sanglah, Denpasar) serta dibantu oleh mahasiswa (panitia dan voluntir). Obat dan alat kesehatan dipersiapkan oleh mahasiswa panitia bersumber dari dana kegiatan, sumbangan BEM FK Unud, sumbangan dari Dinas Kesehatan Provinsi Bali dan sumbangan swadaya dari apotek. Kegiatan ini dilaksanakan pada tanggal 3 September 2016 pada pukul 09.00 S.d 13.00.

\section{HASIL DAN PEMBAHASAN}

Penyuluhan: Kegiatan penyuluhan diikuti seluruh siswa SD 1 Gegelang. Diawali dengan pemberian materi mengenai cara mencuci tangan dan menyikat gigi yang benar dilanjutkan dengan peragaan cuci tangan dan sikat gigi interaktif yang dipimpin oleh satu mahasiswa panitia dan diikuti oleh seluruh siswa SD 1 Gegelang. Setelah itu dilaksanakan senam bersama sebagai bentuk pengenalan perilaku hidup sehat. Kegiatan ini mendapatkan respon sangat positif yang ditunjukan dengan sikap aktif dan antusias dari siswa SD.

Pelayanan Kesehatan Telinga Hidung Tenggorokan: kegiatan pemeriksaan THT dilakukan di ruang kelas SD 1 Gegelang. Pemeriksaan dilakukan oleh dokter spesialis THT kemudian dilakukan tindakan pembersihan telinga dan pemberian obat secara langsung bagi yang terindikasi. Mahasiswa panitia dan voluntir membantu dalam penyiapan alat dan obat serta edukasi penggunaan obat. Pada saat pemeriksaan, siswa SD 1 Gegelang sangat kooperatif sehingga pemeriksaan berjalan dengan lancar.

Pemeriksaan THT dilakukan pada 76 siswa SD 1 Gegelang yang terdiri dari 37 laki-laki dan 39 perempuan. Hasil pemeriksaan ditemukan bahwa sebagian besar siswa dengan status THT normal. Diantara siswa yang memiliki masalah THT, permasalahan dominan adalah adanya serumen 
telinga yang perlu dibersihkan yaitu sebanyak $25 \%$ dari seluruh siswa, diikuti dengan infeksi saluran pernapasan atas (ISPA) yang berupa rhinitis, tonsilitis, sinusitis, tonsilofaringitis, maupun rinofaringitis, dengan rincian dapat dilihat pada grafik 1 dibawah.

\section{Graflk Data Diagnosis THT Siswa SD 1 Gegelang}
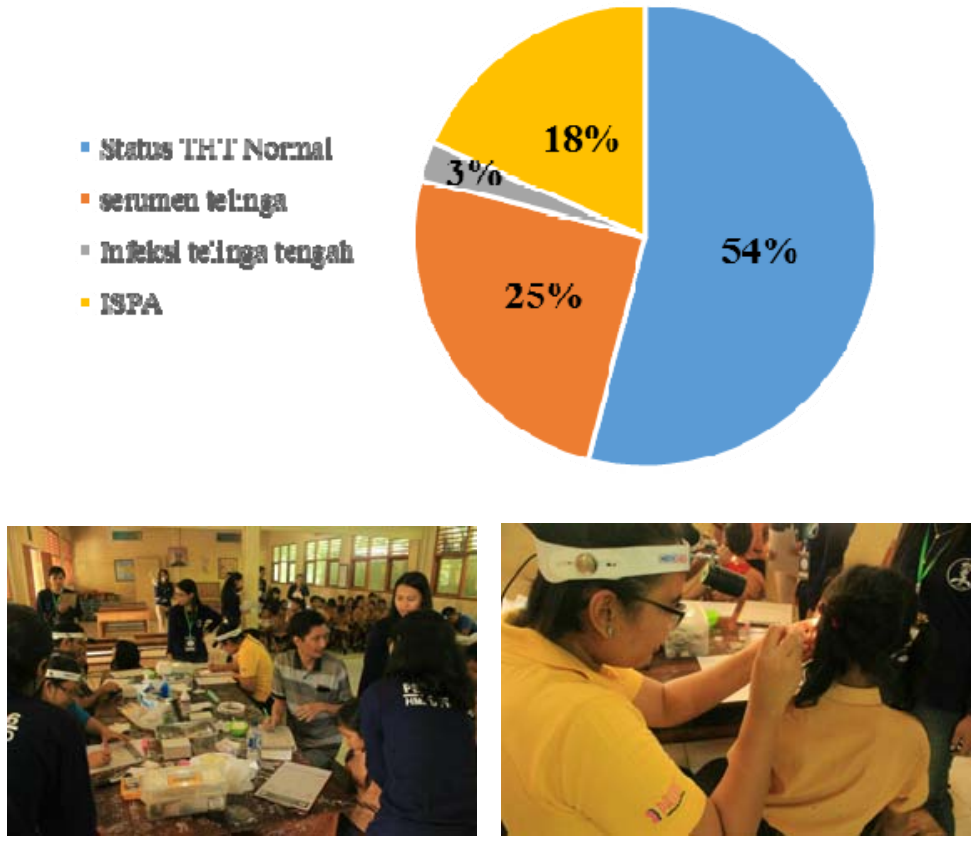

Gambar 1. Pemeriksaan THT

Prevalensi $25 \%$ ini merupakan nilai yang cukup tinggi yang mungkin merupakan pengaruh dari tingkat sosial ekonomi masyarakat desa Gegelang yang berada pada tingkat menengah kebawah. Sosial ekonomi diyakini berpengaruh pada pembentukan serumen pada kelas menengah kebawah karena lingkungan yang cenderung lebih kering, berdebu, dan kotor. Tingkat sosial ekonomi rendah juga cenderung meningkatkan stres yang dapat mengaktifkan sistem adrenergik yang meningkatkan proses pembentukan serumen obsturan (Maharddhika 2010). Diantara 25\% pasien yang memiliki serumen, $13 \%$ diantaranya mengalami serumen obsturan, yaitu serumen yang telah menutupi liang telinga. Hal ini ditakutkan dapat mengganggu pendengaran siswa dan berpengaruh pada proses belajar mengajar siswa yang mengalami gangguan tersebut (Hydri \& Siddiqui, 2016). Gangguan proses mendengar pada usia belajar akan sangat merugikan karena tidak bisa menyerap pelajaran secara maksimal.

Hasil pemeriksaan THT ini menunjukan masih perlu dilakukan upaya promotif dan preventif yang salah satunya merupakan pelayanan kesehatan yang menyertakan kegiatan pembersihan serumen telinga pada tempat-tempat yang terpencil untuk memfasilitasi siswa usia belajar yang belum memiliki pengetahuan ataupun akses untuk membersihkan telinganya secara baik.

Penelitian: Ditemukan 31,7\% dari 126 siswa menderita kecacingan, dengan penyebab terbanyak adalah Trichuris trichuria (75\%), diikuti Ascaris Lumbricoides (17,5\%) dan infeksi ganda kedua cacing $(7,5 \%)$. Terdapat faktor yang ditemukan berhubungan dengan kecacingan yaitu kebiasaan tidak menggunakan alas kaki $(\mathrm{OR}=4,88 ; 95 \% \mathrm{CI} 1,15-20,65)$, tidak menggunting kuku rutin $(\mathrm{OR}=3,33 ; 95 \% \mathrm{CI} 1,07-10,37)$, dan tidak memiliki jamban di rumah $(\mathrm{OR}=4,31 ; 95 \% \mathrm{CI} 1,93-9,64)$. Angka prevalensi $31,7 \%$ cukup tinggi, riwayat pengobatan massal dengan obat cacing dosis

\section{3 | BULETIN UDAYANA MENGABDI}


K.A.R.S. Sentana, K.A. Wiryadana, J.R. Pranata, P.D.S. Rahayu, I.G.A.D.P. Anjani, J.M.A.D. Septiantari, A.R. Dewi, K.A.I. Pitaloka, I.P.G.O. Jaya, I.G.H. Ganesha

tunggal tidak \pm 2 minggu sebelumnya tidak memberikan efek protektif. Tidak ditemukan hubungan antara status kecacingan dengan status gizi yang buruk, walaupun sebagian siswa memilki status gizi yang dibawah nilai rekomendasi WHO. Hasil penelitian lebih lengkap telah dipublikasikan secara terpisah yang dapat dilihat pada tautan https://www.paediatricaindonesiana.org/index.php/paediatrica-indonesiana/article/view/1571

(Wiryadana et al. 2017).

Pelayanan Kesehatan: Pelayanan kesehatan diikuti oleh 107 orang (55 laki-laki dan 52 perempuan) yang berasal dari warga desa Gegelang dan sekitarnya. Peserta berasal dari berbagai golongan usia dengan rincian 8 balita (0-5 tahun), 21 orang anak-anak (6-12 tahun), 1 orang remaja (13-17 tahun), 45 orang dewasa (18-59 tahun) dan 32 lansia ( $\geq 60$ tahun). Hasil pemeriksaan tanda vital dari semua peserta rata-rata berada pada nilai normal, kecuali tekanan darah pada pada beberapa orang (grafik 2.d). Walaupun 44 orang memiliki tekanan darah diatas nilai normal, belum dapat disimpulkan menderita hipertensi karena belum memenuhi kriteria yaitu tekanan darah diatas $>140 / 90$ pada minimal 2 kali pengukuran (Chobanian et al. 2003).

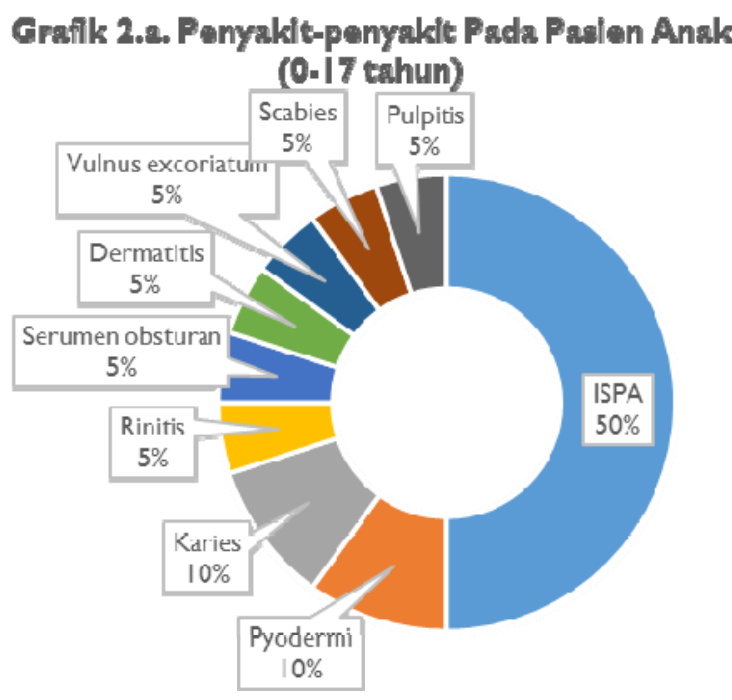

Gambar 2. Penyakit-penyakit Pada Pasien Anak (0-17 tahun)

\section{Graflk 2.b. Penyaklt-penyaklt pada Paselen Lansla (260 tahun)}

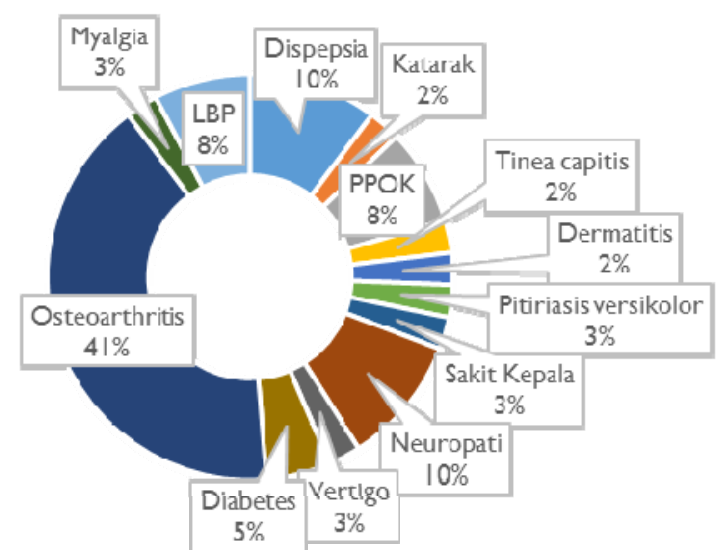

Gambar 3. Penyakit-penyakit pada Pasien Lansia ( $\geq 60$ tahun) 


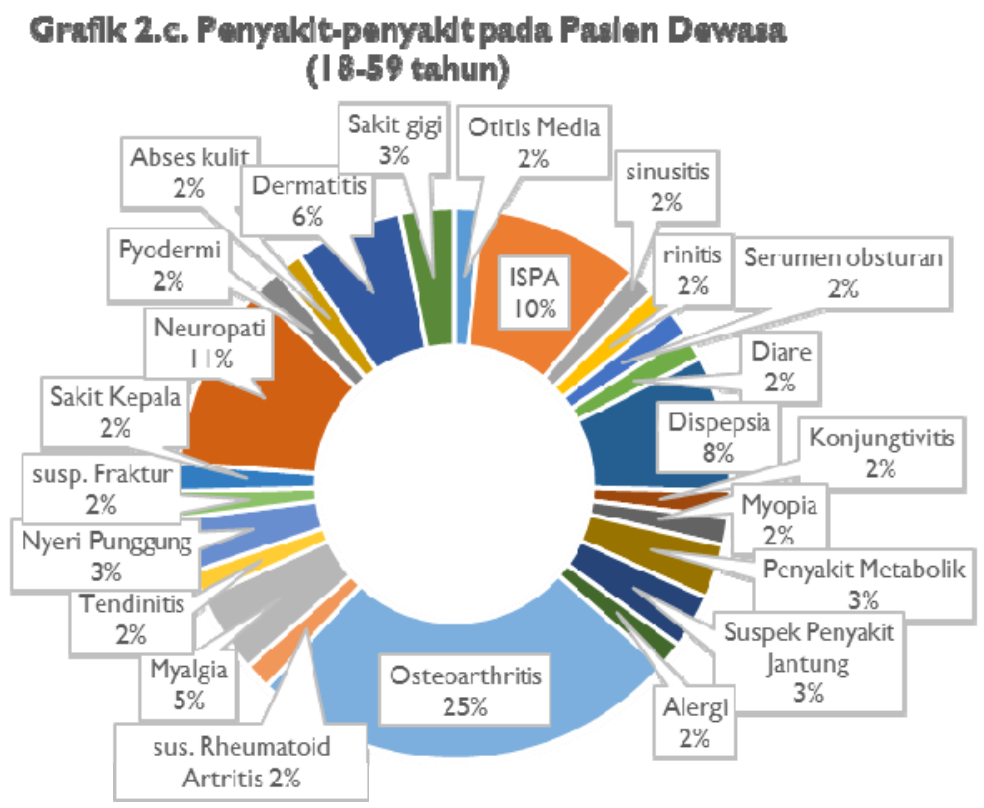

Gambar 4. Penyakit-penyakit pada Pasien Dewasa (18-59 tahun)
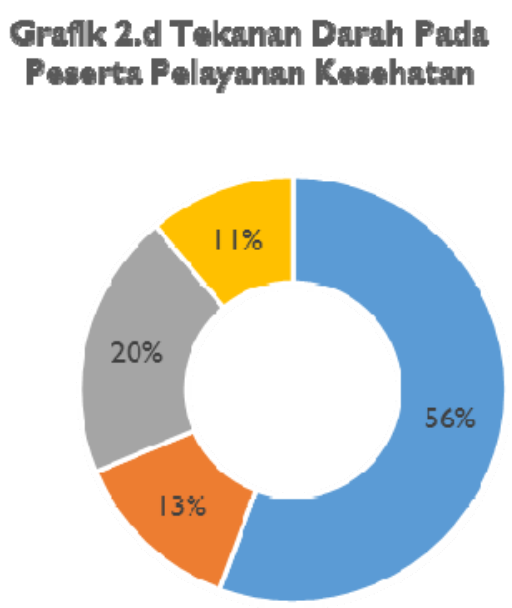

$$
\begin{aligned}
& \text { - } 4120-129 / 80-89 \text { | 120-139/80-89 } \\
& \text { | 140-159/90-99 = - }-60 / 100
\end{aligned}
$$

Gambar 4. Tekanan Darah Pada Peserta Pelayanan Kesehatan

Data penyakit peserta pelayanan kesehatan ditambiplan pada grafik $2 \mathrm{a}, 2 \mathrm{~b}$ dan $2 \mathrm{c}$. Penyakit yang paling sering ditemukan adalah Osteroarthritis (nyeri sendi degeneratif) yang diderita oleh 32 orang terutama pada pasien dewasa dan lansia. Penyakit infeksi saluran pernapasan atas (ISPA) merupakan penyakit yang dominan pada pasien anak, dan merupakan penyakit yang paling sering ditemui pada pelayanan kesehatan ini setelah osteoarthritis. ISPA juga dikeluhkan oleh pasien dewasa, dan memiliki porsi yang hampir sama dengan nyeri neuropati. Sebagian besar pasien 
K.A.R.S. Sentana, K.A. Wiryadana, J.R. Pranata, P.D.S. Rahayu, I.G.A.D.P. Anjani, J.M.A.D. Septiantari, A.R. Dewi, K.A.I. Pitaloka, I.P.G.O. Jaya, I.G.H. Ganesha

datang dengan keluhan nyeri, baik nyeri muskuloskeletal, nyeri kepala, nyeri gigi dan lain-lainnya, sehingga memerlukan pengobatan simptomatis anti nyeri (analgesik). Hal dapat digunakan sebagai acuan untuk pelayanan kesehatan selanjutnya agar mempersiapkan obat anti nyeri yang efektif dan dalam kuantitas yang mencukupi karena obat analgesik merupakan obat yang paling banyak diresepkan pada pelayanan kesehatan ini.

\section{KESIMPULAN DAN SARAN}

Berdasarkan hasil kegiatan maka dapat disimpulkan bahwa :

a. Kegiatan PENITI disambut baik oleh masyarakat Desa Gegelang dengan antusiasme tinggi siswa SD 1 dan SD 3 Gegelang selama penyuluhan dan penelitian serta keikutsertaan 107 orang masyarakat untuk memperoleh pelayanan kesehatan gratis.

b. Sebagian besar siswa SD 1 Gegelang yang memiliki status THT normal, akan tetapi $25 \%$ siswa menderita gangguan serumen, $13 \%$ diantaranya merupakan serumen obsturan.

c. Ditemukan $31,7 \%$ dari 126 siswa SD 1 Gegelang menderita kecacingan, dengan penyebab terbanyak Trichuris trichuria walaupun telah dilakukan pengobatan kecacingan masal.

d. Penyakit yang paling sering terjadi berdasarkan usia yaitu osteoarthritis pada dewasa dan lansia serta ISPA pada anak-anak. Nyeri (sendi, otot, gigi) menjadi keluhan paling banyak dialami sehingga pemberian analgesik sebagai pengobatan sangat tinggi.

Adapun saran yang dapat diberikan adalah memperhatikan antusias masyarakat maka kegiatan sejenis berupa penelitian dan pelayanan kesehatan perlu dilakukan secara berkelanjutan dan dengan jangkauan lebih luas.

\section{UCAPAN TERIMAKASIH}

Dengan terlaksananya Pelayanan Kesehatan dan Penelitian 2016 ini, kami mengucapkan terima kasih kepada pihak PSPD dan HMKU atas alokasi dananya. Terima kasih kepada BEM FK Unud, Dinas Kesehatan Provinsi Bali dan Apotek yang telah memberikan sumbangan dana dan obat-obatan. Terima kasih kepada para dosen/dokter FK Unud atas partisipasinya serta segenap panitia dan voluntir yang tidak bisa disebutkan namanya satu persatu di artikel ini.

\section{DAFTAR PUSTAKA}

Chan, L., Hart, L.G. \& Goodman, D.C., 2006. Geographic Access to Health Care for Rural Medicare Beneficiaries. The Journal of Rural Health, 22(2), pp.140-146.

Chobanian, A. V. et al., 2003. Seventh report of the Joint National Committee on Prevention, Detection, Evaluation, and Treatment of High Blood Pressure. Hypertension, 42(6), pp.1206-1252.

Hydri, S.A. \& Siddiqui, F., 2016. Hearing Loss Due To Different Types of Impacted Cerumen. Sci Med Central Ann Otolaryngol Rhino, 3(2), pp.2014-2017.

Maharddhika, M. Faktor-Faktor yang mempengaruhi pembentukan serumen obsturan [thesis]. Semarang: Universitas Diponegoro; 2010.

Satar, R.M. et al., 2013. Penimgkatan Derajat Kesehatan Melalui Promosi Kesehatan Pola Hidup Bersih Dan Sehat (PHBS) Di Dusun Sawahan Desa Pendowoharjo Kecamatan Sewon Kabupaten Bantul. Khazanah, 6(1), pp.27-33. 
Singh, A.R. \& Singh, S.A., 2008. Diseases of poverty and lifestyle, well-being and human development. Mens sana monographs, 6(1), pp.187-225.

Thomas, D. \& Frankenberg, E., 2002. Health, nutrition and prosperity: A microeconomic perspective. Bulletin of the World Health Organization, 80(2), pp.106-113.

Wiryadana, K.A. et al., 2017. Risk factors of soil-transmitted helminth infection among elementary school students. Paediatrica Indonesiana, 57(6), pp.295-302.

Witteman, H.O. et al., 2013. Facilitating interdisciplinary collaboration to tackle complex problems in health care. Health Systems, 2(3), pp.162-170. 